\title{
Field interpretation of earth remote sensing data and ground field surveys in the Republic of Kazakhstan, Kostanay region in the pre-sowing season
}

\author{
Sabit Ismuratov $^{1 *}$, Aida Dukeyeva ${ }^{I}$, Saniya Abiltaevna Tulkubayeva ${ }^{2}$, and Yuriy \\ Valerievich Tulayev ${ }^{2}$ \\ ${ }^{I}$ Kostanay Engineering and Economics University named after M.Dulatov, 110000, Chernyshevsky \\ st.,59, Kostanay, Republic of Kazakhstan \\ ${ }^{2}$ Limited Liability Company «Agricultural experimental station «Zarechnoye», 111108, Yubileinaya \\ st., 12, Zarechnoye village, Kostanay district, Kostanay region, Republic of Kazakhstan
}

\begin{abstract}
The aim of the research is to carry out field and office work on conducting a sub-satellite survey on test sites of the Kostanay region of the Republic of Kazakhstan. Grain-sowing districts of the Kostanay region were selected as the objects of examination: Karabalyk, Fedorov, Mendykara, Uzunkol, Sarykol, Altynsarin, Kostanay, Denisov, Karasu, Taranov, Zhitikara, Auliekol, Kamysty, Naurzum. The determination of the reserves of productive soil moisture in the $0-100 \mathrm{~cm}$ layer by control points (100 points) carried out in the pre-sowing season of 2019 showed that the soils are characterized by satisfactory and, for the most part, insufficient moisture. The fields fixed in the coordinate system were evaluated by five indicators - $\mathrm{pH}$, humus, nitrate nitrogen (N-NO3), mobile phosphorus (P2O5), and exchange potassium (K2O). Most of the soils examined had a soil solution reaction that was neutral or close to neutral. In terms of humus content, soils of the Karabalyk, Fedorov, Uzunkol and Sarykol districts had an average degree of availability, which exceeded the indicators of other districts of the Kostanai region and depended on the type of soil. The content of the basic elements of plant nutrition - nitrogen and phosphorus - varied within various limits, and, to a large extent, was determined by the previous culture, tillage, fertilizer application, and climatic conditions of the year. The level of exchangeable potassium in the soils of the examined districts of the Kostanay region was characterized as elevated or very high.
\end{abstract}

\section{Introduction}

There is a rapid growth in the introduction of digital technology in the solution of agricultural issues, the field of crop cultivation is especially active. And in this direction the technology of precision farming occupies a special place [1]. The introduction of precision

* Corresponding author: adm@kineu.kz 
farming elements will significantly increase production efficiency. The elements of precision farming include: electronic field maps, data from a weather station, sensors and sensors for differential application of both fertilizers and herbicides, space monitoring which preliminary shows the presence of both vegetation and all other necessary data for farmers to work [2].With the help of geological positioning systems, satellite images and maps of agrochemical field surveys, farmers are given the opportunity to absolutely accurately apply fertilizers, process the fields, determine crop seeding rates and crop rotation patterns. As a result, costs are reduced, and the return of arable land is growing at times. In real time, the main aspects of agriculture are monitored, the level of moisture and mineralization of the soil, the level of light that plants feed on is estimated. [3], [4].

The digitization of the fields carried out today allows the farmer to submit online applications for various types of sub-granting.

Digital technologies offer Kazakhstan farmers equal opportunities with foreign right now.

The purpose of digitalization of the agro-industrial complex is to increase productivity and efficiency through the introduction of digital technologies. In the process of digitalization, electronic field maps are created. To date, 24 million hectares of arable land have been digitized, almost $100 \%$ of the total sown area. Also, work has begun on digitizing pastures. Farm productivity is boosted by technologies such as:

- prediction of optimal time for harvesting

- "smart watering"

- intelligent mineral fertilizer application system

- pest and weed control system

- $\quad$ systematic crop rotation system

Such a concept as "precision farming" is based on a deep and thorough analysis of soil composition [5]. On traditional farms, one analysis per 75 ha is carried out. On smart farms, the soil for analysis is taken from each hectare. This method helps to more accurately determine the volume and composition of fertilizers, and also determines the most suitable methods of cultivating the land. A lot of work is performed by artificial intelligence in the form of computer programs, while manual labor is minimal. Computer systems can simultaneously process large amounts of data and constantly adapt the conditions for the favorable growth of agricultural products. As part of a pilot project on the introduction of precision farming, 9 Kazakhstani farms are already using new technologies and are showing excellent results. The best of the best digitization of the agro-industrial complex lead Akmola, Kostanai and Karaganda regions. Kostanay region produces $22 \%$ of the total grain volume in the country and $27 \%$ of the total volume of food products falls on the Kostanay region. [6] In the region, 20 agricultural enterprises with good production indicators and efficient growth and development were selected for the implementation of digitalization [7], [8].

\section{Literature review}

Environmental monitoring is a comprehensive system for observing the state of the environment, assessing and forecasting changes in its state under the influence of natural and anthropogenic factors. Monitoring involves a process of systematic or continuous collection of information on environmental parameters to determine trends in their changes. Monitoring can be carried out using a network of stationary points, however, observations at individual points or profiles do not always reflect spatial changes. Therefore, the use of aerial and satellite images (Earth remote sensing data - RS) is a prerequisite for regular observations of the current state of ecosystems. Comparing them with the results of surveys 
performed in past decades allows you to accurately capture the changes that have occurred.[9].

Remote sensing is the process by which information about an object, territory or phenomenon is collected without direct contact with it. Remote sensing includes all types of non-contact surveys that are conducted from various measuring platforms: aircraft and spacecraft (airplanes, helicopters, spaceships, satellites, etc.), ships and submarines, ground stations [10]. In this case, a snapshot is defined as a two-dimensional metric image of specific objects, obtained purposefully as a result of remote registration and (or) measurement of intrinsic or reflected radiation, and represents the most appropriate form of measuring, recording and visualizing radiation that carries geographical information about the objects being studied. Over the past decades, the volume, variety and quality of remote sensing materials have increased significantly. To date, a huge fund (more than 100 million) of aerospace images has been accumulated, fully covering the entire surface of the Earth, and for a significant part of the regions with multiple overlapping. [11], [12]

The success of using multi-temporal, heterogeneous, with varying degrees of detail shooting data, as well as all available cartographic materials, depends on the involvement of modern geographic information technologies. It is advisable to create geographic information systems of a local level that can combine detailed thematic and general geographic data, materials from aerial and space surveys of different years, the results of stationary observations at test sites and other additional data available in the studied area of protected areas.[13],[14].

The prospective development of digital automated systems for photogrammetric processing, as well as systems for automatic decryption and transmission of images, requires an effective approach for the description and modeling of images. Any image can be characterized as the result of displaying at a fixed point in time and a given limited surface or plane a set of integrated radiation or reflection sources (decomposition elements, pixels) located outside a given surface.

The aim of the research is to carry out field and office work on conducting a subsatellite survey on test sites of the Kostanay region of the Republic of Kazakhstan.

The article was prepared as part of the implementation of the republican budget program 010 "Ensuring the safety and expansion of the use of space infrastructure" subprogram 102 "Services for the provision of satellite images to government bodies and organizations received from the space system of remote sensing of the Earth of the Republic of Kazakhstan".

\section{Materials and methods}

The central Kazakhstan province includes 2 zones: a dry-steppe zone with subzones of dark chestnut and chestnut soils with an area of 8180.6 thousand ha, including farmland 7661.7 thousand ha, arable land - 2186.6 thousand ha and semi-desert zone with a subzone of light chestnut soils, with an area of 3209.2 thousand ha, including farmland - 2944.2 thousand ha.

Aral-Balkhash province includes a desert zone, with a subzone of brown desert soils. Its area is 1624.6 thousand ha, including farmland 1436.1 thousand ha.

The vast territory of the Kostanay region caused very significant differences in climatic conditions, soil cover structure and soil quality.

Changes in bioclimatic factors in the meridional direction influenced the allocation of three soil zones in the region: a) chernozem zone; b) the area of chestnut soils; c) the zone of brown soils of the northern desert. Their presence is associated with an increase in aridity of the climate from north to south. 
At the same time, the hydrothermal coefficient varies from north to south from 0.9 to 0.3 , the annual rainfall is from 360 to $175 \mathrm{~mm}$ or less, and the wetting coefficient is from 0.37 to 0.09 . The sum of active temperatures in the north of the region is $2400^{\circ} \mathrm{C}$, in the south $-3100^{\circ} \mathrm{C}$.

A very significant change in agroclimatic factors affected the soil fertility of the region. High-fertile chernozems of moderately arid steppes, with a humus content in the arable layer of up to $6 \%$, pass in the south into almost barren ( $0.8 \%$ of organic matter) brown soils of the northern desert.

The soils of the region are very diverse. It is enough to note that more than 1,500 soil varieties are identified on its territory.

According to the soil survey, the main structural units of the region's soils are represented by the following subtypes: ordinary chernozems - 2.9 million ha; southern chernozems - 3.2 million hectares; dark chestnut soils - 3.9 million ha; chestnut soils - 3.7 million hectares; light chestnut - 2.9 million hectares; brown soils - 1.4 million hectares.

The best soils in the region are ordinary chernozems. They are located in the north of the region, within the West Siberian Lowland and partially the Trans-Ural Plateau. They are distinguished by high fertility, favorable agrophysical and chemical properties. Their lowhumus species prevail, containing 4-6\% humus in the arable layer. These soils are characterized by high absorption capacity, the absorption capacity is $35-40 \mathrm{mg}$ / equiv. per $100 \mathrm{~g}$ of soil. Their soil absorbing complex is saturated with calcium. The soil reaction is neutral $(\mathrm{pH}=7)$ or slightly alkaline $(\mathrm{pH}=7.2-7.5)$. The mechanical composition of the soil is heavy and medium loamy. Light loamy and sandy loamy varieties are found in small massifs; they are less humus-rich (2-3\% humus), are low-structural, and can undergo deflation. It should be noted the presence of carbonate taxa in these soils, characterized by increased alkalinity and worse agrophysical properties. Quite widespread (up to 450 thousand ha) among ordinary chernozems are complexes of solonetzes and solonetzic chernozems. These soils are characterized by negative agrophysical and chemical properties. Their use as part of arable land is highly undesirable.

The subzone of southern chernozems is located within the southern margin of the West Siberian Lowland, the Predturgay Plain, and the Trans-Ural Plateau and occupies the central part of the region. A large difference in geographical terms caused the formation in the region, among the black earths of the southern, significant areas of solonetzes, saline and rocky soils, which often in combination with zonal soils, negatively affect the fertility of the latter. Compared to chernozems of the northern regions of the region, chernozems of the south are characterized by smaller reserves of organic matter. Low humus species prevail among them, with a humus content in the arable layer of 3.5-4.0\%, and in varieties of light mechanical composition from $1.8 \%$ to $3 \%$. Among southern chernozems carbonate soils of heavy mechanical composition are also widespread.

Significant areas in the south of the region are occupied by dark chestnut soils, which were formed within the northern part of the Turgai canteen of the country. Among the dark chestnut soils, carbonate genera and varieties of light (sandy loam) mechanical composition prevail. Soils differ sharply in fertility, agrophysical and chemical compositions. Sandysand varieties are characterized by a very low content of organic matter $-1.5-2.0 \%$, fragilelumpy structure, and eroded varieties are generally structureless. Their absorption capacity is very low, the absorption capacity is $10-12 \mathrm{mg} /$ equiv. per $100 \mathrm{~g}$ of soil. These are the most low-yielding soils of the region. The carbonate genera of dark chestnut soils are characterized by much better properties. They are more fertile. They contain up to $3.5 \%$ humus in the arable layer. Their mechanical composition is loamy and clayey.

Similar properties have chestnut carbonate soils, which prevail in the subzone of chestnut soils, but they are less fertile, their humus content does not exceed $3 \%$.

Most of the soils described above are used in agricultural production as arable land. 
In the extreme south of the region, in the zone of very dry steppes and the northern desert, light chestnut and brown soils formed. They are characterized by a sandy mechanical composition, low organic matter content of $0.8 \%$ and very low natural fertility. They are used as grazing land.

Grain-sowing districts of Kostanay region were selected as objects of examination: Karabalyk, Fedorovsky, Mendykarinsky, Uzunkolsky, Sarykolsky, Altynsarinsky, Kostanaysky, Denisovsky, Karasusky, Taranovsky, Zhitikarinsky, Auliekolsky, Kamystinsky, Naurzum.

Determination of productive soil moisture reserves in a meter soil layer was carried out at 100 control points in the pre-sowing period.

The $\mathrm{pH}$ of the soil, the content of humus and mineral nutrition elements (NPK) in the seed soil layer $(0-30 \mathrm{~cm})$ were determined by 100 control points in the pre-sowing period.

Laboratory agrochemical analysis of the selected soil samples was carried out in accordance with the following regulatory documents:

GOST 28268-89 Soil.Methods for determining moisture, maximum hygroscopic humidity and moisture of sustainable wilting of plants.

GOST 26483-85.The soil.Preparation of salt extract and determination of its $\mathrm{pH}$ according to the method of the Central Research Institute of Agrochemical Services.

GOST 26213-91.The soil.Methods for the determination of organic matter.

GOST 26951-86.The soil.Determination of nitrates by the ionometric method.

GOST 26204-91.The soil.Determination of mobile compounds of phosphorus and potassium according to the Chirikov method as modified by the Central Scientific Research Institute of Agrochemical Services.

GOST 26205-91.The soil.Determination of mobile compounds of phosphorus and potassium by the method of Machigin in modification Central Research Institute of Agrochemical Services.

\section{Results}

The main objectives of the research are:

- implementation of field and desk work to conduct a satellite-based survey on test sites of the Kostanay region of the Republic of Kazakhstan;

- determination of stocks of productive soil moisture in a layer of $0-100 \mathrm{~cm}$ from control points (100 points), carried out in the pre-sowing season of 2019

Sampling for the productive moisture of the meter layer of soil was carried out according to the list of control points on the map of the districts: Karabalyksky - 7 points; Fedorovsky district - 13 points; Mendykarinsky district - 7 points; Uzunkol district - 6 points; Sarykol district - 4 points; Altynsarinsky district - 5 points; Kostanay district - 10 points; Denisovsky district - 7 points; Karasu district - 12 points; Taranovsky district - 3 points; Auliekol district - 7 points; Zhitikarinsky district - 3 points; Kamystinsky district 10 points; Naurzum district - 6 points (Figure 1). 

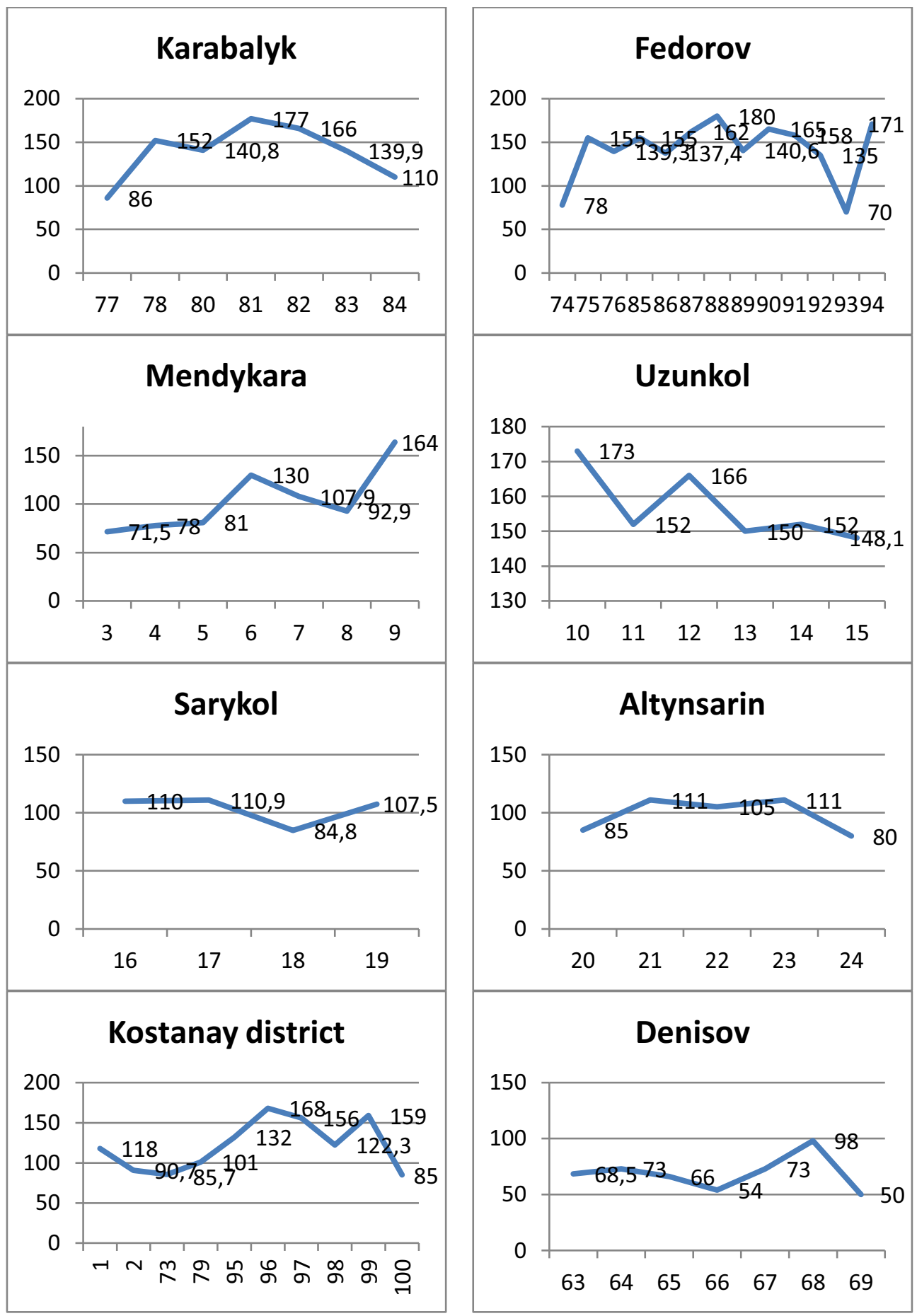

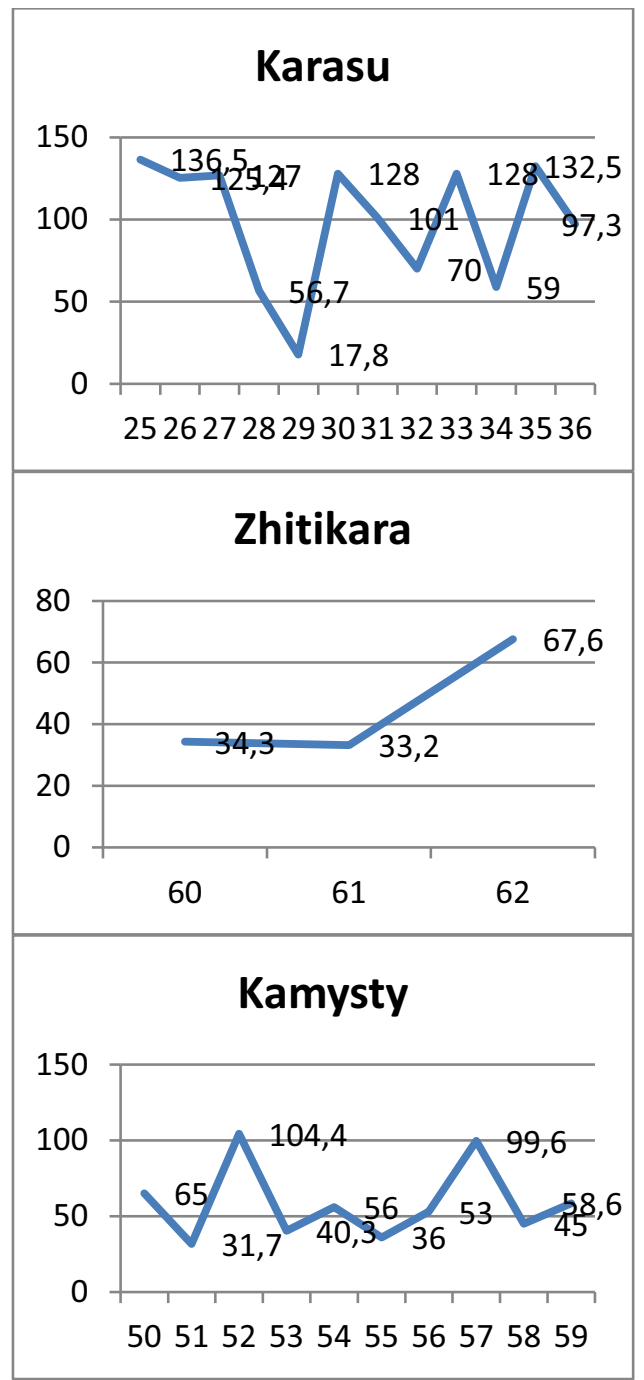

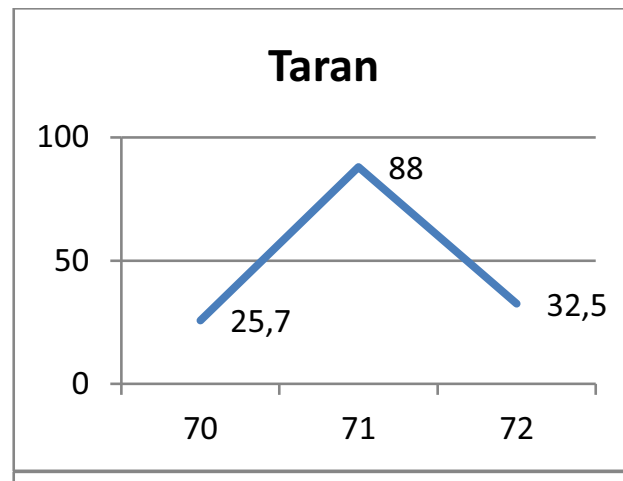

Auliekol

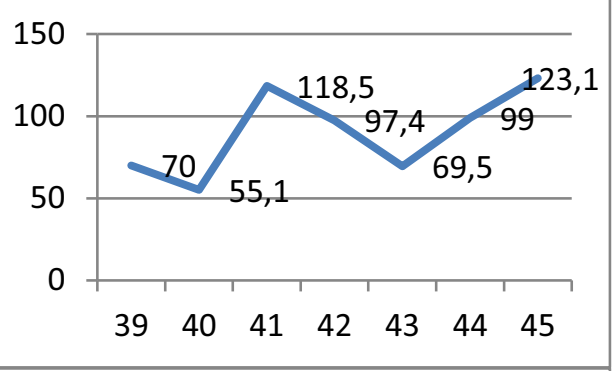

Naurzum

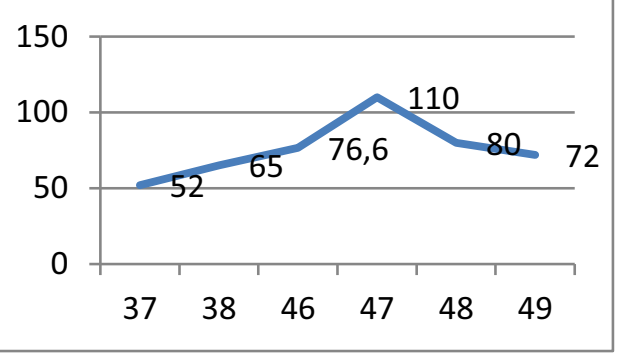

Fig. 1. Reserves of productive moisture in the $0-100 \mathrm{~cm}$ soil layer $(\mathrm{mm})$ at the control points of the districts of the Kostanay region in the pre-sowing season of 2019

Soil moisture was determined by the selected samples using a soil drill from $0-100 \mathrm{~cm}$ layer using the thermostat-weight method (drying soil samples in an oven at a temperature of $105^{\circ} \mathrm{C}$ ). The weights of weights were weighed after sampling, and after drying and by the difference in soil mass, the reserves of productive moisture were determined [15] (table $1)$.

Table 1 Assessment of productive moisture reserves in the soil (A.F. Vadyunina, Z.A. Korchagina)

\begin{tabular}{|c|c|c|l|}
\hline $\begin{array}{c}\text { The thickness of the } \\
\text { soil layer, } \mathrm{cm}\end{array}$ & $\begin{array}{c}\text { Water } \\
\text { reserves, } \mathrm{mm}\end{array}$ & Number of points & \multicolumn{1}{|c|}{ Quality assessment } \\
\hline \multirow{3}{*}{$0-100$} & $>160$ & 10 & very good \\
\cline { 2 - 4 } & $160-130$ & 19 & good \\
\cline { 2 - 4 } & $130-90$ & 28 & satisfactory \\
\cline { 2 - 4 } & $90-60$ & 25 & bad \\
\hline
\end{tabular}




\begin{tabular}{|l|l|l|l|}
\hline & $<60$ & 18 & very bad \\
\hline
\end{tabular}

The moisture indicator of a meter layer of soil ranged from 17.8 to $173.0 \mathrm{~mm}$. Of the given 100 points for sampling moisture in 18 , soil moisture was below $50 \%$ of the lowest field moisture capacity. In the rest, from 50 to $67 \%$ of the lowest field moisture capacity with the norm adopted for typical soils of $170-180 \mathrm{~mm}$.

The greatest moisture reserves were recorded in the northern regions of the Kostanai region located in the zone of ordinary chernozems: Fedorovsky - up to $180 \mathrm{~mm}$ (Figure 2), Karabalyksky - up to $177 \mathrm{~mm}$, Uzunkolsky - up to $173 \mathrm{~mm}$, Mendykarinsky - up to 164 $\mathrm{mm}$. In addition, very good moisture reserves (up to $168 \mathrm{~mm}$ ) were observed in the Kostanay region, located in the zone of southern chernozems. It is worth noting that in the Karasu region both very good moisture reserves were found $-136.5 \mathrm{~mm}$, and the lowest $17.8 \mathrm{~mm}$ (Figure 3). With the advance to the south of the region (the zone of dark chestnut and chestnut soils), there was a gradual decrease in productive moisture reserves in the soil: Auliekol district - up to $55.1 \mathrm{~mm}$, Kamystinsky - up to $31.7 \mathrm{~mm}$, Naurzumsky - up to 52 $\mathrm{mm}$.

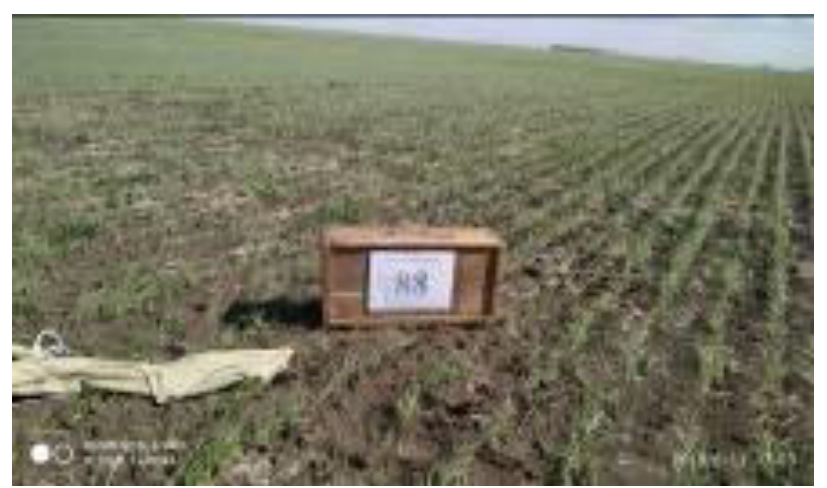

Fig. 2. Control point No. 88 (Fedorovsky district), the highest content of productive moisture in the 0$100 \mathrm{~cm}$ soil layer $-180.0 \mathrm{~mm}$

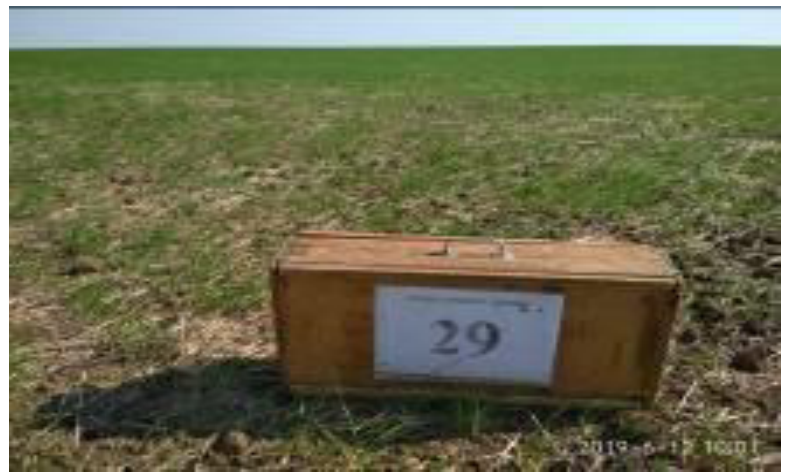

Fig. 3. Control point No. 29 (Karasu district), the lowest content of productive moisture in the 0-100 $\mathrm{cm}$ soil layer - $17.8 \mathrm{~mm}$

To determine the $\mathrm{pH}$ of the soil, the content of humus and elements of mineral nutrition in the seed soil layer at each test site, combined soil samples were taken from a soil layer of 0-30 cm for subsequent laboratory agrochemical analysis (Figure 4). [16] 


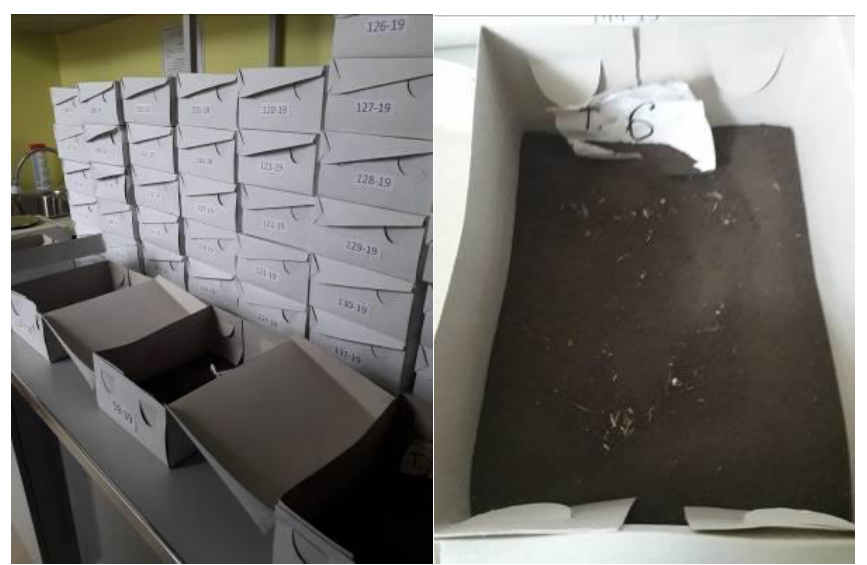

Fig. 4. Soil samples for agrochemical soil analysis, 2019.

The Machigin method is designed to extract mobile compounds of phosphorus and potassium from the soil and is accepted as standard for carbonate chernozems, chestnut, brown, brown soils and serozems. To extract mobile phosphorus and potassium from noncarbonate soils, the standard Chirikov method is adopted. Therefore, laboratory agrochemical analysis of soil samples was performed depending on the type of soil (table 2).

The fields fixed in the coordinate system were evaluated by five indicators - $\mathrm{pH}$, humus, nitrate nitrogen (N-NO3), mobile phosphorus (P2O5), and exchange potassium (K2O).

Most of the soils examined had a soil solution reaction that was neutral or close to neutral, which is favorable for most cultivated agricultural crops. of cultures.[17]

In terms of humus content, the soils of Karabalyksky (4.22-5.40\%), Fedorovsky (4.17$5.39 \%$ ), Uzunkolsky (4.85-5.37\%) and Sarykolsky (4.10-5.19\%) of the districts, which exceeded the indicators of the remaining districts of the Kostanay region and depended on the type of soil.

The content of the basic elements of plant nutrition - nitrogen and phosphorus varied within various limits, and, to a large extent, was determined by the previous culture, tillage, fertilizer application, and climatic conditions of the year. Especially drastic changes depending on these conditions are subject to the content of nitrates in the soil.

The level of exchangeable potassium in the soils of the examined districts of the Kostanay region was characterized as elevated or very high.

Table 2. The content of nutrients in soils at control points of the districts of the Kostanay region in the pre-sowing season of 2019.

\begin{tabular}{|c|c|c|c|c|c|c|c|c|c|c|c|}
\hline \multirow{2}{*}{$\begin{array}{c}\text { Contr } \\
\text { ol } \\
\text { point } \\
\text { numb } \\
\text { er }\end{array}$} & \multirow[t]{2}{*}{ Coordinates } & \multicolumn{10}{|c|}{ Content in the soil layer (combined sample), $0-30 \mathrm{~cm}$} \\
\hline & & $\mathrm{pH}$ & $\begin{array}{c}\text { environ } \\
\text { ment }\end{array}$ & $\begin{array}{c}\text { humu } \\
\mathrm{s}, \%\end{array}$ & $\begin{array}{c}\text { degree } \\
\text { of } \\
\text { security }\end{array}$ & $\begin{array}{c}\mathrm{N} \\
\text { general } \\
\left(\mathrm{NO}_{3}\right)\end{array}$ & $\begin{array}{c}\text { degree } \\
\text { of } \\
\text { security }\end{array}$ & $\mathrm{P}_{2} \mathrm{O}_{5}$ & $\begin{array}{c}\text { degree } \\
\text { of } \\
\text { security }\end{array}$ & $\mathrm{K}_{2} \mathrm{O}$ & $\begin{array}{c}\text { degree } \\
\text { of } \\
\text { security }\end{array}$ \\
\hline \multicolumn{12}{|c|}{ Karabalyk district } \\
\hline 77 & $\begin{array}{l}62^{\circ} 16^{\prime} 3,503^{\prime \prime} \mathrm{E} \\
53^{\circ} 10^{\prime} 54,964^{\prime \prime} \mathrm{N}\end{array}$ & 6,18 & neutral & 4,26 & average & 6,5 & low & 127 & $\begin{array}{c}\text { increase } \\
\mathrm{d}\end{array}$ & 138 & high \\
\hline 78 & $\begin{array}{l}62^{\circ} 9^{\prime} 47,186^{\prime \prime} \mathrm{E} \\
53^{\circ} 17^{\prime} 40,206^{\prime \prime} \mathrm{N}\end{array}$ & 6,69 & neutral & 4,43 & average & 12,3 & average & 7 & $\begin{array}{l}\text { very } \\
\text { low* }\end{array}$ & 421 & $\begin{array}{l}\text { very } \\
\text { high* }\end{array}$ \\
\hline 80 & $\begin{array}{l}61^{\circ} 54^{\prime} 59,291^{\prime \prime} \mathrm{E} \\
53^{\circ} 27^{\prime} 21,722^{\prime \prime} \mathrm{N}\end{array}$ & 6,21 & neutral & 5,09 & average & 10,7 & average & 31 & low & 138 & high \\
\hline 81 & $\begin{array}{l}61^{\circ} 52^{\prime} 30,583^{\prime \prime} \mathrm{E} \\
53^{\circ} 33^{\prime} 44,684^{\prime \prime} \mathrm{N}\end{array}$ & 6,62 & neutral & 5,40 & average & 31,0 & high & 69 & average & 404 & $\begin{array}{l}\text { very } \\
\text { high }\end{array}$ \\
\hline 82 & $\begin{array}{l}61^{\circ} 57^{\prime} 25,870^{\prime \prime} \mathrm{E} \\
53^{\circ} 37^{\prime} 4,150^{\prime \prime} \mathrm{N}\end{array}$ & 6,77 & neutral & 4,22 & average & 10,7 & average & 9 & $\begin{array}{l}\text { very } \\
\text { low }\end{array}$ & 470 & $\begin{array}{l}\text { very } \\
\text { high* }\end{array}$ \\
\hline 83 & $\begin{array}{l}62^{\circ} 3^{\prime} 22,190^{\prime \prime} \mathrm{E} \\
53^{\circ} 40^{\prime} 13,527^{\prime \prime} \mathrm{N}\end{array}$ & 6,84 & neutral & 4,27 & average & 9,6 & low & 64 & average & 336 & $\begin{array}{l}\text { very } \\
\text { high }\end{array}$ \\
\hline 84 & $62^{\circ} 7^{\prime} 8,560^{\prime \prime} \mathrm{E}$ & 5,72 & close to & 4,43 & average & 5,1 & low & 67 & average & 132 & high \\
\hline
\end{tabular}




\begin{tabular}{|c|c|c|c|c|c|c|c|c|c|c|c|}
\hline & $53^{\circ} 44^{\prime} 23,896^{\prime \prime} \mathrm{N}$ & & neutral & & & & & & & & \\
\hline \multicolumn{12}{|c|}{ Fedorov district } \\
\hline 74 & $\begin{array}{l}62^{\circ} 50^{\prime} 13,607 " \mathrm{E} \\
53^{\circ} 26^{\prime} 47,768^{\prime \prime} \mathrm{N}\end{array}$ & 6,34 & neutral & 3,55 & low & 9,8 & low & 40 & low & 272 & $\begin{array}{l}\text { very } \\
\text { high }\end{array}$ \\
\hline 75 & $\begin{array}{l}62^{\circ} 42^{\prime} 9,986 " \mathrm{E} \\
53^{\circ} 28^{\prime} 4,260^{\prime \prime} \mathrm{N}\end{array}$ & 6,70 & neutral & 3,76 & low & 18,6 & high & 24 & low & 108 & $\begin{array}{c}\text { increase } \\
\mathrm{d}\end{array}$ \\
\hline 76 & $\begin{array}{l}62^{\circ} 30^{\prime} 28,541^{\prime \prime} \mathrm{E} \\
53^{\circ} 15^{\prime} 31,067^{\prime \prime} \mathrm{N}\end{array}$ & 6,89 & neutral & 4,85 & average & 10,2 & average & 0 & $\begin{array}{l}\text { very } \\
\text { low }\end{array}$ & 192 & $\begin{array}{l}\text { very } \\
\text { high }\end{array}$ \\
\hline 85 & $\begin{array}{l}62^{\circ} 18^{\prime} 50,636^{\prime \prime} \mathrm{E} \\
53^{\circ} 43^{\prime} 59,407^{\prime \prime} \mathrm{N}\end{array}$ & 6,41 & neutral & 4,88 & average & 4,7 & $\begin{array}{l}\text { very } \\
\text { low }\end{array}$ & 64 & average & 198 & $\begin{array}{l}\text { very } \\
\text { high }\end{array}$ \\
\hline 86 & $\begin{array}{l}62^{\circ} 34^{\prime} 49,880^{\prime \prime} \mathrm{E} \\
53^{\circ} 39^{\prime} 58,809^{\prime \prime} \mathrm{N}\end{array}$ & 6,37 & neutral & 4,40 & average & 9,1 & low & 56 & average & 336 & $\begin{array}{l}\text { very } \\
\text { high }\end{array}$ \\
\hline 87 & $\begin{array}{l}62^{\circ} 42^{\prime} 16.2^{\prime \prime} \mathrm{E} \\
53^{\circ} 39^{\prime} 58.5^{\prime \prime} \mathrm{N}\end{array}$ & 6,60 & neutral & 4,55 & average & 8,7 & low & 75 & average & 300 & $\begin{array}{l}\text { very } \\
\text { high }\end{array}$ \\
\hline 88 & $\begin{array}{l}62^{\circ} 44^{\prime} 32,093 " \mathrm{E} \\
53^{\circ} 49^{\prime} 33,820^{\prime \prime} \mathrm{N}\end{array}$ & 6,74 & neutral & 5,17 & average & 12,3 & average & 12 & low* & 583 & $\begin{array}{l}\text { very } \\
\text { high* }\end{array}$ \\
\hline 89 & $\begin{array}{l}62^{\circ} 53^{\prime} 41,721^{\prime \prime} \mathrm{E} \\
53^{\circ} 55^{\prime} 59,569^{\prime \prime} \mathrm{N}\end{array}$ & 6,50 & neutral & 5,20 & average & 10,0 & average & 183 & high & 576 & $\begin{array}{l}\text { very } \\
\text { high }\end{array}$ \\
\hline 90 & $\begin{array}{l}63^{\circ} 1^{\prime} 24,876^{\prime \prime} \mathrm{E} \\
53^{\circ} 58^{\prime} 13,874 " \mathrm{~N}\end{array}$ & 6,49 & neutral & 5,39 & average & 28,8 & high & 79 & average & 366 & $\begin{array}{l}\text { very } \\
\text { high }\end{array}$ \\
\hline 91 & $\begin{array}{l}63^{\circ} 13^{\prime} 18,278^{\prime \prime} \mathrm{E} \\
53^{\circ} 58^{\prime} 41,666^{\prime \prime} \mathrm{N}\end{array}$ & 6,47 & neutral & 4,97 & average & 10,2 & average & 123 & $\begin{array}{c}\text { increase } \\
\mathrm{d}\end{array}$ & 402 & $\begin{array}{l}\text { very } \\
\text { high }\end{array}$ \\
\hline 92 & $\begin{array}{l}63^{\circ} 8^{\prime} 39,232^{\prime \prime} \mathrm{E} \\
53^{\circ} 50^{\prime} 2,021^{\prime \prime} \mathrm{N}\end{array}$ & 6,63 & neutral & 5,32 & average & 34,7 & high & 8 & $\begin{array}{l}\text { very } \\
\text { low* }\end{array}$ & 648 & $\begin{array}{l}\text { very } \\
\text { high* }\end{array}$ \\
\hline 93 & $\begin{array}{l}63^{\circ} 16^{\prime} 32,181^{\prime \prime} \mathrm{E} \\
53^{\circ} 44^{\prime} 14,323^{\prime \prime} \mathrm{N}\end{array}$ & 6,78 & neutral & 4,26 & average & 4,1 & $\begin{array}{l}\text { very } \\
\text { low }\end{array}$ & 39 & low & 564 & $\begin{array}{l}\text { very } \\
\text { high }\end{array}$ \\
\hline 94 & $\begin{array}{l}63^{\circ} 18^{\prime} 16,446 " \mathrm{E} \\
53^{\circ} 41^{\prime} 42,512^{\prime \prime} \mathrm{N}\end{array}$ & 6,74 & neutral & 4,17 & average & 9,1 & low & 9 & $\begin{array}{l}\text { very } \\
\text { low* }\end{array}$ & 486 & $\begin{array}{c}\text { very } \\
\text { high* }\end{array}$ \\
\hline \multicolumn{12}{|c|}{ Mendykara district } \\
\hline 3 & $\begin{array}{l}64^{\circ} 9^{\prime} 16,359^{\prime \prime} \mathrm{E} \\
53^{\circ} 38^{\prime} 25,764^{\prime \prime} \mathrm{N}\end{array}$ & 5,98 & $\begin{array}{l}\text { close to } \\
\text { neutral }\end{array}$ & 3,03 & low & 11,0 & average & 52 & average & 216 & high \\
\hline 4 & $\begin{array}{l}64^{\circ} 10^{\prime} 54,141^{\prime \prime} \mathrm{E} \\
53^{\circ} 42^{\prime} 12,874 " \mathrm{~N}\end{array}$ & 5,60 & $\begin{array}{l}\text { close to } \\
\text { neutral }\end{array}$ & 3,35 & low & 9,1 & low & 39 & low & 138 & high \\
\hline 5 & $\begin{array}{l}64^{\circ} 11^{\prime} 40,741^{\prime \prime} \mathrm{E} \\
53^{\circ} 44^{\prime} 17,091^{\prime \prime} \mathrm{N}\end{array}$ & 5,52 & $\begin{array}{l}\text { slightly } \\
\text { acidic }\end{array}$ & 3,21 & low & 8,9 & low & 32 & low & 144 & high \\
\hline 6 & $\begin{array}{l}64^{\circ} 27^{\prime} 25,126^{\prime \prime} \mathrm{E} \\
53^{\circ} 48^{\prime} 21,800^{\prime \prime} \mathrm{N}\end{array}$ & 6,18 & neutral & 2,98 & low & 9,8 & low & 39 & low & 210 & high \\
\hline 7 & $\begin{array}{l}64^{\circ} 50^{\prime} 57,216^{\prime \prime} \mathrm{E} \\
54^{\circ} 1^{\prime} 34,565^{\prime \prime} \mathrm{N}\end{array}$ & 6,05 & neutral & 3,73 & low & 12,9 & average & 69 & average & 396 & $\begin{array}{l}\text { very } \\
\text { high }\end{array}$ \\
\hline 8 & $\begin{array}{l}64^{\circ} 49^{\prime} 26,118^{\prime \prime} \mathrm{E} \\
54^{\circ} 8^{\prime} 9,068^{\prime \prime} \mathrm{N}\end{array}$ & 6,37 & neutral & 4,67 & average & 14,8 & average & 61 & average & 474 & $\begin{array}{l}\text { very } \\
\text { high }\end{array}$ \\
\hline 9 & $\begin{array}{l}64^{\circ} 46^{\prime} 52,166^{\prime \prime} \mathrm{E} \\
54^{\circ} 18^{\prime} 19,520^{\prime \prime} \mathrm{N}\end{array}$ & 5,98 & $\begin{array}{l}\text { close to } \\
\text { neutral }\end{array}$ & 3,03 & low & 11,0 & average & 52 & average & 216 & $\begin{array}{l}\text { very } \\
\text { high }\end{array}$ \\
\hline \multicolumn{12}{|c|}{ Uzunkol district } \\
\hline 10 & $\begin{array}{l}64^{\circ} 54^{\prime} 32,193 " \mathrm{E} \\
54^{\circ} 18^{\prime} 34,320^{\prime \prime} \mathrm{N}\end{array}$ & 6,55 & neutral & 4,88 & average & 47,4 & high & 50 & average & 348 & $\begin{array}{l}\text { very } \\
\text { high }\end{array}$ \\
\hline 11 & $\begin{array}{l}65^{\circ} 0^{\prime} 3,340^{\prime \prime} \mathrm{E} \\
54^{\circ} 14^{\prime} 51,448^{\prime \prime} \mathrm{N}\end{array}$ & 6,69 & neutral & 5,37 & average & 17,0 & high & 15 & $\begin{array}{c}\text { average } \\
*\end{array}$ & 593 & $\begin{array}{l}\text { very } \\
\text { high* }\end{array}$ \\
\hline 12 & $\begin{array}{l}65^{\circ} 13^{\prime} 42,761^{\prime \prime} \mathrm{E} \\
54^{\circ} 10^{\prime} 58,758^{\prime \prime} \mathrm{N}\end{array}$ & 6,40 & neutral & 4,85 & average & 17,0 & high & 11 & low* & 567 & $\begin{array}{c}\text { very } \\
\text { high* }\end{array}$ \\
\hline 13 & $\begin{array}{l}65^{\circ} 18^{\prime} 8,651^{\prime \prime} \mathrm{E} \\
54^{\circ} 3^{\prime} 24,275^{\prime \prime} \mathrm{N}\end{array}$ & 6,04 & neutral & 5,20 & average & 25,7 & high & 68 & average & 312 & $\begin{array}{l}\text { very } \\
\text { high }\end{array}$ \\
\hline 14 & $\begin{array}{l}65^{\circ} 18^{\prime} 28,477^{\prime \prime} \mathrm{E} \\
53^{\circ} 52^{\prime} 44,044^{\prime \prime} \mathrm{N}\end{array}$ & 5,81 & $\begin{array}{l}\text { close to } \\
\text { neutral }\end{array}$ & 4,96 & average & 14,1 & average & 45 & low & 204 & $\begin{array}{l}\text { very } \\
\text { high }\end{array}$ \\
\hline 15 & $\begin{array}{l}65^{\circ} 24^{\prime} 0,592^{\prime \prime} \mathrm{E} \\
53^{\circ} 43^{\prime} 51,249^{\prime \prime} \mathrm{N}\end{array}$ & 6,39 & neutral & 5,32 & average & 14,8 & average & 76 & average & 276 & $\begin{array}{l}\text { very } \\
\text { high }\end{array}$ \\
\hline \multicolumn{12}{|c|}{ Sarykol district } \\
\hline 16 & $\begin{array}{l}6^{\circ} 28^{\prime} 41,529^{\prime \prime} \mathrm{E} \\
53^{\circ} 40^{\prime} 2,963^{\prime \prime} \mathrm{N}\end{array}$ & 6,37 & neutral & 4,57 & average & 14,8 & average & 63 & average & 282 & $\begin{array}{l}\text { very } \\
\text { high }\end{array}$ \\
\hline 17 & $\begin{array}{l}65^{\circ} 33^{\prime} 27,133^{\prime \prime} \mathrm{E} \\
53^{\circ} 29^{\prime} 36,481^{\prime \prime} \mathrm{N}\end{array}$ & 6,46 & neutral & 5,19 & average & 16,6 & high & 88 & average & 396 & $\begin{array}{l}\text { very } \\
\text { high }\end{array}$ \\
\hline 18 & $\begin{array}{l}65^{\circ} 32^{\prime} 46,086^{\prime \prime} \mathrm{E} \\
53^{\circ} 21^{\prime} 14,978^{\prime \prime} \mathrm{N}\end{array}$ & 6,53 & neutral & 4,15 & average & 7,4 & low & 93 & average & 324 & $\begin{array}{l}\text { very } \\
\text { high }\end{array}$ \\
\hline 19 & $\begin{array}{l}65^{\circ} 15^{\prime} 31.3^{\prime \prime} \mathrm{E} \\
53^{\circ} 19^{\prime} 31.3^{\prime \prime} \mathrm{N}\end{array}$ & 6,45 & neutral & 4,10 & average & 21,9 & high & 49 & low & 378 & $\begin{array}{l}\text { very } \\
\text { high }\end{array}$ \\
\hline \multicolumn{12}{|c|}{ Altynsarin district } \\
\hline 20 & $\begin{array}{l}64^{\circ} 48^{\prime} 21,409^{\prime \prime} \mathrm{E} \\
53^{\circ} 15^{\prime} 33,066^{\prime \prime} \mathrm{N}\end{array}$ & 5,65 & $\begin{array}{l}\text { close to } \\
\text { neutral }\end{array}$ & 3,43 & low & 5,0 & low & 60 & average & 228 & $\begin{array}{l}\text { very } \\
\text { high }\end{array}$ \\
\hline 21 & $\begin{array}{l}64^{\circ} 31^{\prime} 40.9^{\prime \prime} \mathrm{E} \\
53^{\circ} 11^{\prime} 12.2^{\prime \prime} \mathrm{N}\end{array}$ & 5,41 & $\begin{array}{l}\text { slightly } \\
\text { acidic }\end{array}$ & 4,00 & average & 17,8 & high & 83 & average & 366 & $\begin{array}{l}\text { very } \\
\text { high }\end{array}$ \\
\hline 22 & $64^{\circ} 15^{\prime} 48,998^{\prime \prime} \mathrm{E}$ & 5,63 & close to & 2,66 & low & 6,5 & low & 41 & low & 192 & very \\
\hline
\end{tabular}




\begin{tabular}{|c|c|c|c|c|c|c|c|c|c|c|c|}
\hline & $53^{\circ} 9^{\prime} 18,115^{\prime \prime} \mathrm{N}$ & & neutral & & & & & & & & high \\
\hline 23 & $\begin{array}{l}64^{\circ} 33^{\prime} 7,756^{\prime \prime} \mathrm{E} \\
53^{\circ} 0^{\prime} 56,653^{\prime \prime} \mathrm{N} \\
\end{array}$ & 6,55 & neutral & 3,15 & low & 12,6 & average & 9 & $\begin{array}{l}\text { very } \\
\text { low* }\end{array}$ & 642 & $\begin{array}{c}\text { very } \\
\text { high* }\end{array}$ \\
\hline 24 & $\begin{array}{l}64^{\circ} 51^{\prime} 43,890^{\prime \prime} \mathrm{E} \\
53^{\circ} 0^{\prime} 34,460^{\prime \prime} \mathrm{N}\end{array}$ & 5,95 & $\begin{array}{l}\text { close to } \\
\text { neutral }\end{array}$ & 3,56 & low & 17,8 & high & 52 & average & 270 & $\begin{array}{l}\text { very } \\
\text { high }\end{array}$ \\
\hline \multicolumn{12}{|c|}{ Kostanay district } \\
\hline 1 & $\begin{array}{l}63^{\circ} 52^{\prime} 57,993^{\prime \prime} \mathrm{E} \\
53^{\circ} 17^{\prime} 12,032^{\prime \prime} \mathrm{N}\end{array}$ & 6,30 & neutral & 4,49 & average & 12,3 & average & 18 & $\begin{array}{c}\text { average } \\
* \\
\end{array}$ & 300 & high* \\
\hline 2 & $\begin{array}{l}63^{\circ} 55^{\prime} 52,318^{\prime \prime} \mathrm{E} \\
53^{\circ} 19^{\prime} 38,163^{\prime \prime} \mathrm{N} \\
\end{array}$ & 5,77 & $\begin{array}{l}\text { close to } \\
\text { neutral }\end{array}$ & 3,84 & low & 7,4 & low & 48 & low & 373 & $\begin{array}{l}\text { very } \\
\text { high }\end{array}$ \\
\hline 73 & $\begin{array}{l}62^{\circ} 54^{\prime} 3,269^{\prime \prime} \mathrm{E} \\
53^{\circ} 9^{\prime} 41,109^{\prime \prime} \mathrm{N}\end{array}$ & 6,53 & neutral & 3,63 & low & 5,1 & low & 43 & low & 282 & $\begin{array}{l}\text { very } \\
\text { high }\end{array}$ \\
\hline 79 & $\begin{array}{l}63^{\circ} 47^{\prime} 24.7^{\prime \prime} \mathrm{E} \\
53^{\circ} 12^{\prime} 15.7^{\prime \prime} \mathrm{N} \\
\end{array}$ & 6,61 & neutral & 3,13 & low & 6,0 & low & 42 & low & 398 & $\begin{array}{l}\text { very } \\
\text { high }\end{array}$ \\
\hline 95 & $\begin{array}{l}3^{\circ} 21^{\prime} 16,063^{\prime \prime} \mathrm{E} \\
53^{\circ} 35^{\prime} 54,365^{\prime \prime} \mathrm{N}\end{array}$ & 6,85 & neutral & 3,63 & low & 20,0 & high & 13 & low* & 469 & $\begin{array}{c}\text { very } \\
\text { high* }\end{array}$ \\
\hline 96 & $\begin{array}{l}63^{\circ} 23^{\prime} 07.1^{\prime \prime} \mathrm{E} \\
53^{\circ} 33^{\prime} 55.5^{\prime \prime} \mathrm{N}\end{array}$ & 6,75 & neutral & 4,09 & average & 10,2 & average & 15 & $\begin{array}{c}\text { average } \\
*\end{array}$ & 454 & $\begin{array}{c}\text { very } \\
\text { high* }\end{array}$ \\
\hline 97 & $\begin{array}{l}63^{\circ} 20^{\prime} 25,531^{\prime \prime} \mathrm{E} \\
53^{\circ} 31^{\prime} 22,103^{\prime \prime} \mathrm{N}\end{array}$ & 6,82 & neutral & 3,65 & low & 9,8 & low & 8 & $\begin{array}{l}\text { very } \\
\text { low* }\end{array}$ & 486 & $\begin{array}{c}\text { very } \\
\text { high* }\end{array}$ \\
\hline 98 & $\begin{array}{l}63^{\circ} 21^{\prime} 12,648^{\prime \prime} \mathrm{E} \\
53^{\circ} 25^{\prime} 11,156^{\prime \prime} \mathrm{N}\end{array}$ & 6,86 & neutral & 3,83 & low & 6,5 & low & 71 & average & 192 & $\begin{array}{l}\text { very } \\
\text { high }\end{array}$ \\
\hline 99 & $\begin{array}{l}63^{\circ} 30^{\prime} 16,415^{\prime \prime} \mathrm{E} \\
53^{\circ} 18^{\prime} 45,292^{\prime \prime} \mathrm{N}\end{array}$ & 6,80 & neutral & 3,36 & low & 11,2 & average & 6 & $\begin{array}{l}\text { very } \\
\text { low* }\end{array}$ & 518 & $\begin{array}{l}\text { very } \\
\text { high* }\end{array}$ \\
\hline 100 & $\begin{array}{l}63^{\circ} 32^{\prime} 40,733^{\prime \prime} \mathrm{E} \\
53^{\circ} 17^{\prime} 26,204^{\prime \prime} \mathrm{N}\end{array}$ & 6,36 & neutral & 3,35 & low & 3,6 & $\begin{array}{l}\text { very } \\
\text { low }\end{array}$ & 34 & low & 150 & high \\
\hline \multicolumn{12}{|c|}{ Denisov district } \\
\hline 63 & $\begin{array}{l}61^{\circ} 34^{\prime} 14,4^{\prime \prime} \mathrm{E} \\
52^{\circ} 19^{\prime} 26,3^{\prime \prime} \mathrm{N} \\
\end{array}$ & 6,79 & neutral & 2,60 & low & 6,0 & low & 57 & average & 168 & high \\
\hline 64 & $\begin{array}{l}61^{\circ} 42^{\prime} 53,013^{\prime \prime} \mathrm{E} \\
52^{\circ} 30^{\prime} 50,263^{\prime \prime} \mathrm{N}\end{array}$ & 6,77 & neutral & 4,32 & average & 9,1 & low & 8 & $\begin{array}{l}\text { very } \\
\text { low* }\end{array}$ & 551 & $\begin{array}{c}\text { very } \\
\text { high* }\end{array}$ \\
\hline 65 & $\begin{array}{l}61^{\circ} 39^{\prime} 0,825^{\prime \prime} \mathrm{E} \\
52^{\circ} 35^{\prime} 35,257^{\prime \prime} \mathrm{N}\end{array}$ & 6,90 & neutral & 3,60 & low & 6,0 & low & 6 & $\begin{array}{l}\text { very } \\
\text { low* }\end{array}$ & 356 & $\begin{array}{c}\text { very } \\
\text { high* }\end{array}$ \\
\hline 66 & $\begin{array}{l}61^{\circ} 35^{\prime} 51,279^{\prime \prime} \mathrm{E} \\
52^{\circ} 44^{\prime} 26,441^{\prime \prime} \mathrm{N}\end{array}$ & 6,99 & neutral & 3,15 & low & 7,2 & low & 7 & $\begin{array}{l}\text { very } \\
\text { low* }\end{array}$ & 227 & $\begin{array}{c}\text { very } \\
\text { high* }\end{array}$ \\
\hline 67 & $\begin{array}{l}61^{\circ} 34^{\prime} 31,544^{\prime \prime} \mathrm{E} \\
52^{\circ} 41^{\prime} 55,674^{\prime \prime} \mathrm{N}\end{array}$ & 7,06 & neutral & 4,24 & average & 7,2 & low & 6 & $\begin{array}{l}\text { very } \\
\text { low* }\end{array}$ & 356 & $\begin{array}{c}\text { very } \\
\text { high* }\end{array}$ \\
\hline 68 & $\begin{array}{l}61^{\circ} 36^{\prime} 7,624^{\prime \prime} \mathrm{E} \\
52^{\circ} 37^{\prime} 40,689^{\prime \prime} \mathrm{N}\end{array}$ & 6,49 & neutral & 3,11 & low & 7,4 & low & 77 & average & 528 & $\begin{array}{l}\text { very } \\
\text { high }\end{array}$ \\
\hline 69 & $\begin{array}{l}61^{\circ} 41^{\prime} 41,486^{\prime \prime} \mathrm{E} \\
52^{\circ} 29^{\prime} 21,315^{\prime \prime} \mathrm{N}\end{array}$ & 6,75 & neutral & 4,38 & average & 10,9 & average & 8 & $\begin{array}{l}\text { very } \\
\text { low* }\end{array}$ & 636 & $\begin{array}{c}\text { very } \\
\text { high* }\end{array}$ \\
\hline \multicolumn{12}{|c|}{ Karasu district } \\
\hline 25 & $\begin{array}{l}65^{\circ} 16^{\prime} 54,656^{\prime \prime} \mathrm{E} \\
52^{\circ} 45^{\prime} 22,762^{\prime \prime} \mathrm{N} \\
\end{array}$ & 6,55 & neutral & 4,16 & average & 33,9 & high & 9 & $\begin{array}{l}\text { very } \\
\text { low* }\end{array}$ & 745 & $\begin{array}{c}\text { very } \\
\text { high* }\end{array}$ \\
\hline 26 & $\begin{array}{l}65^{\circ} 24^{\prime} 26,475^{\prime \prime} \mathrm{E} \\
52^{\circ} 40^{\prime} 57,097^{\prime \prime} \mathrm{N}\end{array}$ & 6,70 & neutral & 3,76 & low & 16,6 & high & 6 & $\begin{array}{l}\text { very } \\
\text { low* }\end{array}$ & 551 & $\begin{array}{c}\text { very } \\
\text { high* }\end{array}$ \\
\hline 27 & $\begin{array}{l}65^{\circ} 24^{\prime} 33,884^{\prime \prime} \mathrm{E} \\
52^{\circ} 34^{\prime} 18,219^{\prime \prime} \mathrm{N}\end{array}$ & 6,88 & neutral & 3,43 & low & 23,5 & high & 8 & $\begin{array}{l}\text { very } \\
\text { low* }\end{array}$ & 502 & $\begin{array}{c}\text { very } \\
\text { high* }\end{array}$ \\
\hline 28 & $\begin{array}{l}65^{\circ} 16^{\prime} 55,530^{\prime \prime} \mathrm{E} \\
52^{\circ} 23^{\prime} 45,799^{\prime \prime} \mathrm{N}\end{array}$ & 6,90 & neutral & 3,64 & low & 21,4 & high & 5 & $\begin{array}{l}\text { very } \\
\text { low* }\end{array}$ & 405 & $\begin{array}{c}\text { very } \\
\text { high* }\end{array}$ \\
\hline 29 & $\begin{array}{l}65^{\circ} 4^{\prime} 33,762^{\prime \prime} \mathrm{E} \\
52^{\circ} 19^{\prime} 45,863^{\prime \prime} \mathrm{N}\end{array}$ & 6,97 & neutral & 2,99 & low & 15,9 & high & 9 & $\begin{array}{l}\text { very } \\
\text { low* }\end{array}$ & 418 & $\begin{array}{c}\text { very } \\
\text { high* }\end{array}$ \\
\hline 30 & $\begin{array}{l}65^{\circ} 12^{\prime} 29,191 " \mathrm{E} \\
52^{\circ} 12^{\prime} 21,307^{\prime \prime} \mathrm{N}\end{array}$ & 7,09 & neutral & 3,70 & low & 8,4 & low & 65 & average & 282 & $\begin{array}{l}\text { very } \\
\text { high }\end{array}$ \\
\hline 31 & $\begin{array}{l}65^{\circ} 31^{\prime} 50,583^{\prime \prime} \mathrm{E} \\
52^{\circ} 4^{\prime} 5,7677^{\prime \prime} \mathrm{N}\end{array}$ & 7,07 & neutral & 3,78 & low & 7,2 & low & 79 & average & 402 & $\begin{array}{l}\text { very } \\
\text { high }\end{array}$ \\
\hline 32 & $\begin{array}{l}65^{\circ} 23^{\prime} 3,467^{\prime \prime} \mathrm{E} \\
51^{\circ} 58^{\prime} 28,028^{\prime \prime} \mathrm{N}\end{array}$ & 7,13 & neutral & 3,61 & low & 14,8 & average & 92 & average & 420 & $\begin{array}{l}\text { very } \\
\text { high }\end{array}$ \\
\hline 33 & $\begin{array}{l}65^{\circ} 19^{\prime} 29,727^{\prime \prime} \mathrm{E} \\
51^{\circ} 53^{\prime} 45,291^{\prime \prime} \mathrm{N}\end{array}$ & 7,14 & neutral & 3,67 & low & 9,6 & low & 139 & $\begin{array}{c}\text { increase } \\
\mathrm{d}\end{array}$ & 420 & $\begin{array}{l}\text { very } \\
\text { high }\end{array}$ \\
\hline 34 & $\begin{array}{l}65^{\circ} 13^{\prime} 47,493 " \mathrm{E} \\
51^{\circ} 47^{\prime} 59,850^{\prime \prime} \mathrm{N}\end{array}$ & 7,36 & neutral & 2,96 & low & 8,9 & low & 63 & average & 324 & $\begin{array}{l}\text { very } \\
\text { high }\end{array}$ \\
\hline 35 & $\begin{array}{l}65^{\circ} 12^{\prime} 50,651^{\prime \prime} \mathrm{E} \\
51^{\circ} 38^{\prime} 57,954^{\prime \prime} \mathrm{N}\end{array}$ & 7,47 & neutral & 3,25 & low & 10,7 & average & 79 & average & 342 & $\begin{array}{l}\text { very } \\
\text { high }\end{array}$ \\
\hline 36 & $\begin{array}{l}65^{\circ} 9^{\prime} 10,695^{\prime \prime} \mathrm{E} \\
51^{\circ} 30^{\prime} 36,507^{\prime \prime} \mathrm{N}\end{array}$ & 7,48 & neutral & 3,05 & low & 11,0 & average & 58 & average & 276 & $\begin{array}{l}\text { very } \\
\text { high }\end{array}$ \\
\hline \multicolumn{12}{|c|}{ Taran district } \\
\hline 70 & $\begin{array}{l}62^{\circ} 18^{\prime} 11,792^{\prime \prime} \mathrm{E} \\
52^{\circ} 32^{\prime} 53,103^{\prime \prime} \mathrm{N}\end{array}$ & 6,86 & neutral & 2,85 & low & 11,5 & average & 58 & average & 348 & $\begin{array}{l}\text { very } \\
\text { high }\end{array}$ \\
\hline 71 & $\begin{array}{l}62^{\circ} 38^{\prime} 58,704^{\prime \prime} \mathrm{E} \\
52^{\circ} 42^{\prime} 48,319^{\prime \prime} \mathrm{N}\end{array}$ & 6,44 & neutral & 3,37 & low & 4,9 & $\begin{array}{l}\text { very } \\
\text { low }\end{array}$ & 93 & average & 390 & $\begin{array}{l}\text { very } \\
\text { high }\end{array}$ \\
\hline
\end{tabular}




\begin{tabular}{|c|c|c|c|c|c|c|c|c|c|c|c|}
\hline 72 & $\begin{array}{l}62^{\circ} 50^{\prime} 42,460^{\prime \prime} \mathrm{E} \\
52^{\circ} 50^{\prime} 35,190^{\prime \prime} \mathrm{N}\end{array}$ & 6,39 & neutral & 3,80 & low & 4,0 & $\begin{array}{l}\text { very } \\
\text { low }\end{array}$ & 65 & average & 204 & $\begin{array}{l}\text { very } \\
\text { high }\end{array}$ \\
\hline \multicolumn{12}{|c|}{ Zhitikara district } \\
\hline 60 & $\begin{array}{l}61^{\circ} 31^{\prime} 33,637 " \mathrm{E} \\
52^{\circ} 2^{\prime} 44,102^{\prime \prime} \mathrm{N}\end{array}$ & 7,06 & neutral & 3,49 & low & 8,9 & low & 94 & average & 216 & $\begin{array}{l}\text { very } \\
\text { high }\end{array}$ \\
\hline 61 & $\begin{array}{l}61^{\circ} 20^{\prime} 15,302^{\prime \prime} \mathrm{E} \\
52^{\circ} 9^{\prime} 5,701 " \mathrm{~N}\end{array}$ & 7,02 & neutral & 3,67 & low & 13,8 & low & 79 & average & 222 & $\begin{array}{l}\text { very } \\
\text { high }\end{array}$ \\
\hline 62 & $\begin{array}{l}61^{\circ} 26^{\prime} 6,194^{\prime \prime} \mathrm{E} \\
52^{\circ} 14^{\prime} 22,329^{\prime \prime} \mathrm{N}\end{array}$ & 7,03 & neutral & 3,55 & low & 8,5 & low & 72 & average & 204 & $\begin{array}{l}\text { very } \\
\text { high }\end{array}$ \\
\hline \multicolumn{12}{|c|}{ Auliekol district } \\
\hline 39 & $\begin{array}{l}64^{\circ} 14^{\prime} 22,373 " \mathrm{E} \\
52^{\circ} 11^{\prime} 45,785^{\prime \prime} \mathrm{N}\end{array}$ & 5,93 & $\begin{array}{l}\text { close to } \\
\text { neutral }\end{array}$ & 2,25 & low & 4,4 & $\begin{array}{l}\text { very } \\
\text { low }\end{array}$ & 22 & low & 291 & $\begin{array}{l}\text { very } \\
\text { high }\end{array}$ \\
\hline 40 & $\begin{array}{l}64^{\circ} 10^{\prime} 51,216^{\prime \prime} \mathrm{E} \\
52^{\circ} 16^{\prime} 36,306^{\prime \prime} \mathrm{N}\end{array}$ & 6,26 & neutral & 1,72 & $\begin{array}{l}\text { very } \\
\text { low }\end{array}$ & 3,5 & $\begin{array}{l}\text { very } \\
\text { low }\end{array}$ & 28 & low & 216 & $\begin{array}{l}\text { very } \\
\text { high }\end{array}$ \\
\hline 41 & $\begin{array}{l}64^{\circ} 4^{\prime} 30,081^{\prime \prime} \mathrm{E} \\
52^{\circ} 33^{\prime} 54,700^{\prime \prime} \mathrm{N}\end{array}$ & 6,86 & neutral & 3,20 & low & 6,2 & low & 90 & average & 210 & $\begin{array}{l}\text { very } \\
\text { high }\end{array}$ \\
\hline 42 & $\begin{array}{l}63^{\circ} 59^{\prime} 41,979 " \mathrm{E} \\
52^{\circ} 40^{\prime} 14,313^{\prime \prime} \mathrm{N}\end{array}$ & 5,60 & $\begin{array}{l}\text { close to } \\
\text { neutral }\end{array}$ & 2,49 & low & 7,2 & low & 24 & low & 204 & $\begin{array}{l}\text { very } \\
\text { high }\end{array}$ \\
\hline 43 & $\begin{array}{l}63^{\circ} 56^{\prime} 15,822^{\prime \prime} \mathrm{E} \\
52^{\circ} 44^{\prime} 56,548^{\prime \prime} \mathrm{N}\end{array}$ & 6,02 & neutral & 2,60 & low & 1,7 & $\begin{array}{l}\text { very } \\
\text { low }\end{array}$ & 20 & $\begin{array}{l}\text { very } \\
\text { low }\end{array}$ & 274 & $\begin{array}{l}\text { very } \\
\text { high }\end{array}$ \\
\hline 44 & $\begin{array}{l}63^{\circ} 57^{\prime} 18,438^{\prime \prime} \mathrm{E} \\
52^{\circ} 16^{\prime} 8,546^{\prime \prime} \mathrm{N} \\
\end{array}$ & 5,80 & $\begin{array}{l}\text { close to } \\
\text { neutral }\end{array}$ & 2,37 & low & 2,8 & $\begin{array}{l}\text { very } \\
\text { low }\end{array}$ & 12 & $\begin{array}{l}\text { very } \\
\text { low }\end{array}$ & 84 & $\begin{array}{c}\text { increase } \\
\mathrm{d}\end{array}$ \\
\hline 45 & $\begin{array}{l}63^{\circ} 17^{\prime} 40,024^{\prime \prime} \mathrm{E} \\
51^{\circ} 47^{\prime} 54,210^{\prime \prime} \mathrm{N}\end{array}$ & 6,64 & neutral & 1,83 & $\begin{array}{l}\text { very } \\
\text { low }\end{array}$ & 10,0 & average & 102 & $\begin{array}{c}\text { increase } \\
\mathrm{d}\end{array}$ & 408 & $\begin{array}{l}\text { very } \\
\text { high }\end{array}$ \\
\hline \multicolumn{12}{|c|}{ Kamysty district } \\
\hline 50 & $\begin{array}{l}63^{\circ} 38^{\prime} 26,726^{\prime \prime} \mathrm{E} \\
51^{\circ} 3{ }^{\prime} 12,810^{\prime \prime} \mathrm{N}\end{array}$ & 6,92 & neutral & 2,13 & low & 7,4 & low & 60 & average & 90 & $\begin{array}{c}\text { increase } \\
\mathrm{d}\end{array}$ \\
\hline 51 & $\begin{array}{l}63^{\circ} 38^{\prime} 59,372 " \mathrm{E} \\
51^{\circ} 9^{\prime} 43,230^{\prime \prime} \mathrm{N}\end{array}$ & 7,02 & neutral & 2,60 & low & 6,2 & low & 71 & average & 228 & $\begin{array}{l}\text { very } \\
\text { high }\end{array}$ \\
\hline 52 & $\begin{array}{l}62^{\circ} 23^{\prime} 28,253^{\prime \prime} \mathrm{E} \\
51^{\circ} 31^{\prime} 46,327^{\prime \prime} \mathrm{N}\end{array}$ & 6,94 & neutral & 2,78 & low & 15,5 & high & 67 & average & 162 & high \\
\hline 53 & $\begin{array}{l}62^{\circ} 21^{\prime} 44,487^{\prime \prime} \mathrm{E} \\
51^{\circ} 37^{\prime} 2,153^{\prime \prime} \mathrm{N}\end{array}$ & 6,92 & neutral & 3,07 & low & 5,4 & low & 111 & $\begin{array}{c}\text { increase } \\
\text { d }\end{array}$ & 156 & high \\
\hline 54 & $\begin{array}{l}62^{\circ} 22^{\prime} 0,563^{\prime \prime} \mathrm{E} \\
51^{\circ} 42^{\prime} 43,649^{\prime \prime} \mathrm{N}\end{array}$ & 7,00 & neutral & 2,98 & low & 7,4 & low & 75 & average & 174 & high \\
\hline 55 & $\begin{array}{l}61^{\circ} 59^{\prime} 27,066^{\prime \prime} \mathrm{E} \\
51^{\circ} 47^{\prime} 9,591^{\prime \prime} \mathrm{N}\end{array}$ & 7,04 & neutral & 3,43 & low & 5,9 & low & 65 & average & 198 & $\begin{array}{l}\text { very } \\
\text { high }\end{array}$ \\
\hline 56 & $\begin{array}{l}61^{\circ} 51^{\prime} 11,303^{\prime \prime} \mathrm{E} \\
51^{\circ} 38^{\prime} 29,985^{\prime \prime} \mathrm{N}\end{array}$ & 6,98 & neutral & 3,20 & low & 6,2 & low & 89 & average & 276 & $\begin{array}{l}\text { very } \\
\text { high }\end{array}$ \\
\hline 57 & $\begin{array}{l}61^{\circ} 42^{\prime} 47,325^{\prime \prime} \mathrm{E} \\
51^{\circ} 34^{\prime} 31,744^{\prime \prime} \mathrm{N}\end{array}$ & 6,99 & neutral & 3,72 & low & 11,2 & average & 67 & average & 156 & high \\
\hline 58 & $\begin{array}{l}61^{\circ} 36^{\prime} 32,579 " \mathrm{E} \\
51^{\circ} 40^{\prime} 49,275^{\prime \prime} \mathrm{N}\end{array}$ & 7,04 & neutral & 3,43 & low & 7,4 & low & 72 & average & 162 & high \\
\hline 59 & $\begin{array}{l}61^{\circ} 32^{\prime} 46.9^{\prime \prime} \mathrm{E} \\
52^{\circ} 01^{\prime} 38.3^{\prime \prime} \mathrm{N} \\
\end{array}$ & 7,04 & neutral & 3,33 & low & 9,4 & low & 108 & $\begin{array}{c}\text { increase } \\
\mathrm{d}\end{array}$ & 300 & $\begin{array}{l}\text { very } \\
\text { high }\end{array}$ \\
\hline \multicolumn{12}{|c|}{ Naurzum district } \\
\hline 37 & $\begin{array}{l}64^{\circ} 52^{\prime} 31,5^{\prime \prime} \mathrm{E} \\
51^{\circ} 31^{\prime} 40,0^{\prime \prime} \mathrm{N}\end{array}$ & 7,46 & neutral & 2,84 & low & 16,2 & high & 69 & average & 270 & $\begin{array}{l}\text { very } \\
\text { high }\end{array}$ \\
\hline 38 & $\begin{array}{l}64^{\circ} 53^{\prime} 46,725^{\prime \prime} \mathrm{E} \\
51^{\circ} 39^{\prime} 23,866^{\prime \prime} \mathrm{N}\end{array}$ & 6,46 & neutral & 2,34 & low & 8,1 & low & 49 & low & 258 & $\begin{array}{l}\text { very } \\
\text { high }\end{array}$ \\
\hline 46 & 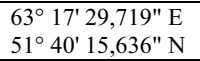 & 6,87 & neutral & 3,31 & low & 11,8 & average & 69 & average & 192 & $\begin{array}{l}\text { very } \\
\text { high }\end{array}$ \\
\hline 47 & $\begin{array}{l}63^{\circ} 42^{\prime} 44,079 " \mathrm{E} \\
51^{\circ} 13^{\prime} 27,350^{\prime \prime} \mathrm{N}\end{array}$ & 6,82 & neutral & 2,13 & low & 5,9 & low & 12 & $\begin{array}{l}\text { very } \\
\text { low }\end{array}$ & 108 & $\begin{array}{c}\text { increase } \\
\mathrm{d}\end{array}$ \\
\hline 48 & $\begin{array}{l}63^{\circ} 35^{\prime} 7,009 " \mathrm{E} \\
51^{\circ} 88^{\prime} 57,764 " \mathrm{~N} \\
\end{array}$ & 6,96 & neutral & 2,96 & low & 33,1 & high & 80 & average & 150 & high \\
\hline 49 & $\begin{array}{l}63^{\circ} 32^{\prime} 55,206^{\prime \prime} \mathrm{E} \\
51^{\circ} 33^{\prime} 55,733^{\prime \prime} \mathrm{N}\end{array}$ & 7,02 & neutral & 2,54 & low & 8,9 & low & 68 & average & 147 & high \\
\hline
\end{tabular}

\section{Discussion}

According to the results of field trips conducted prior to sowing in 2019, it was revealed that $70 \%$ of the surveyed fields in the Kamystinsky district had very low reserves of productive moisture. The study of the remaining control points located outside the zone of ordinary black soils also revealed fields with a very poor degree of supply of productive 
moisture: in the Naurzum district - $17 \%$ of the studied fields, in Zhitikarinsky and Taranovsky districts - $67 \%$ of the fields, in Karasu district - $8 \%$ and in Denisovsky district $28 \%$ of the studied fields.[18]

Assessing the fluctuations in the content of basic nutrients, it is important to emphasize that in the open spaces of Northern Kazakhstan, the leading role belongs to mobile phosphorus along with nitrate nitrogen in the formation of a high-quality crop. In addition, the soils of Northern Kazakhstan, as a rule, are poor in phosphorus. Meanwhile, this element affects the development of the root system, and hence the plant as a whole. In addition, our previous studies show that subsequently it is almost impossible to correct the deficiency of mobile phosphorus in the soil by non-root regulation.[19]

As a result of this work, a deficit of nitrate nitrogen was revealed before sowing in the Kostanay region in $60 \%$ of the fields studied, in Mendykarinsky - $43 \%$ of the fields, in Sarykol $-25 \%$ of the fields, in Altynsarinsky - $40 \%$ of the fields, in Karasu $-33 \%$ of the fields, in Naurzum - $50 \%$ of the fields, in Auelikolsky - $86 \%$ of the fields, in Kamystinsky $80 \%$ of the fields, in Zhitikarinsky - $67 \%$ of the fields, in Denisovsky $-86 \%$ of the fields, Taranovsky $-67 \%$ of the fields, in Fedorovsky - $46 \%$ of the fields, in Karabalyksky $-43 \%$ of the studied fields.

Assessing the deficit of mobile phosphorus, it is worth noting that in the Kostanai region, a low degree of soil supply with this element was observed in $50 \%$ of the fields, and a very low degree in $20 \%$ of the fields. In addition, a low degree of availability of soil with mobile phosphorus was observed in the following districts of the Kostanai region: in Mendykarinsky district - by $43 \%$ of the studied fields, in Uzunkolsky - by $33 \%$ of fields, in Sarykolsky - by $25 \%$ of fields. In the remaining regions, the following picture emerged: some of the fields studied had a low degree of provision with mobile phosphorus, and some were very low. So, in Altynsarinsky district, a low degree of security was observed at $20 \%$ of the fields and another $20 \%$ a very low degree of security, in Karasu district at $42 \%$ of the fields a very low security was observed, in Naurzum district, a low security was observed at $17 \%$ of the fields and $17 \%$ very low degree of security, a low degree of security was observed in $43 \%$ of the fields in Auelikolsky district and $28 \%$ of fields had a very low security level, in Denisovsky district a very low degree of availability of mobile phosphorus was found in Denisovsky district, $31 \%$ in Fedorovsky observed low degree of security and $23 \%$ very low degree of security in the area Karabalyk 14\% of fields observed low degree of security and $29 \%$ of the fields very low degree of security.[20]

\section{Conclusion}

Extremely dry years always cause significant damage to the grain-growing region. However, there are obvious omissions of farmers, because of which weather conditions become the starting point of a number of problems. So, in addition to weather conditions in areas such as Kamystinsky, Taranovsky, Auelikolsky, Zhitikarinsky, Denisovsky and Naurzumsky, there is a lack of a systematic approach to solving agricultural problems, as evidenced by the availability of productive moisture, nitrate nitrogen and mobile phosphorus. One of the solutions to the problem should be more effective short-rotation crop rotation for these areas, working out the issues of mineral nutrition of plants and more efficient assimilation and preservation of autumn-winter precipitation in order to use them productively. 


\section{References}

1 J. Denègre, Thematic Mapping From Satellite Imagery: A Guidebook, 296, (January 1994)

2 Philippe Lagacherie, Alex McBratney, Marc Voltz, Digital Soil Mapping, 658, (December 2006)

3 E.V. Truflyak, Main elements of precision farming system, 39, (Krasnodar: Kubgau, 2016)

4 E.V. Truflyak, Experience of application of precision farming systems, 22, (Krasnodar: Kubgau, 2016)

5 L.-H. LyuSpace, Weather Study Using Multipoint Techniques, 374, (Pergamon, 8th May 2002)

6 URL: https://foodindustry.kz/tsifrovizatsiya-apk-v-kostanajskoj-oblasti/

7 URL: https://tengrinews.kz/kazakhstan_news/tsifrovizatsiya-apk-kostanae-umnyiefermyi-tochnoe-353141/

8 I.A. Labutina, E.A. Baldina, Using remote sensing data for monitoring protected area ecosystems. Methodological guide, I.A. Labutina, E.A. Baldina; world wildlife Fund (WWF of Russia). UNDP / GEF / ICI project Conservation of biodiversity in the Russian part of the Altai-Sayan Ecoregion 88 (Moscow, 2011), Nicolas Baghdadi, Mehrez Zribi , Land Surface Remote Sensing in Agriculture and Forest September, 496, (2016)

9 Methods of remote sensing and GIS technologies for assessing the state of the environment, inventory of land and real estate: Proceedings of the IX international scientific and practical conference, 82 (Italy, May 14-21 2005), M.D. Steven, J.A. Clark, Applications of Remote Sensing in Agriculture, 440 (Butterworth-Heinemann, July 1990)

10 Shunlin Liang, Xiaowen Li Jindi Wang, Advanced Remote Sensing, 800 (Academic Press, August 2012)

11 E.N. Sutyrina, Remote sensing of the earth: textbook manual, 165 (Irkutsk, IGU, 2013)

12 A.A. Vorobyova, Remote sensing of the earth, Educational and methodical manual, 168 (Saint Petersburg, 2012)

13 E.V. Truflyak, Differentiated technologies, 44 (Krasnodar: Kubgau, 2016)

14 A.F. Vadyunina, Z.A. Korchagina, Methods of research of physical properties of soils, 416 (M.: Agropromizdat, 1986)

15 M Frissel, Cycling of Mineral Nutrients in Agricultural Ecosystems, 364, (1st January 1978)

16 Y. Pachepsky, W.J. Rawls, Development of Pedotransfer Functions in Soil Hydrology, Elsevier Science, 542 (November 2004)

17 Janusz Pawliszyn, Sampling and Sample Preparation in Field and Laborator, 1166 (September 2002)

18 Prashant Srivastava, George Petropoulos, Y.H. Kerr, Satellite Soil Moisture Retrieval, 440, (May 2016) 